\title{
Unspecified Anatomic Sites
}

National Cancer Institute

\section{Source}

National Cancer Institute. Unspecified Anatomic Sites. NCI Thesaurus. Code C13411.

Research that isn't focused on a specific site. 